\title{
Contemporary Patriotic Education in the School, Family and Church
}

\section{The concept of patriotic education}

The basic assumption of patriotic education is to shape patriotic attitudes that form the basis of national and cultural identification. Education on such subjects also serves as an element of preparation for living in society. Through its influence on the construction of ties with the mother country, patriotic education is a preparation for the younger generation to perform pro-social roles. Education of this nature should be gradual through didactic and educational activity, while the transmission of patriotic content should be considered as the duty of every teacher regardless of his political beliefs. Patriotism itself expresses itself most fully in attachment to one's homeland, to the family land, to customs and national culture, and in respect for people who were its co-creators. Issues related to patriotic education are also addressed in parts of the regulation (of various rank) of the Polish educational system. The fact that "education and upbringing serves to develop youth's sense of responsibility, love of the homeland and respect for Polish cultural heritage, 
while opening up to the values of cultures of Europe and the world" says the introduction to the Act of 7 September 1991 on the system of education. ${ }^{1}$ Certain provisions of the Teacher's Charter also emphasize that the teacher is obliged to educate young people in loving the Homeland, respecting the Constitution of the Republic of Poland, as well as in the atmosphere of freedom of conscience and respect for every human being. ${ }^{2}$

The role of the school in this perspective is to care for the proper intellectual and moral development of the young generation, including its proper attitude, which should be characterized by patriotism and love of the fatherland, respect for national symbols and colors, and respect for traditions and customs. ${ }^{3}$ The process of patriotic education can be presented in three interrelated aspects. In the first aspect, such education is recognized as a historically defined social phenomenon related to the achieved level of maturity of a given community, expressing itself in the organization and continuous improvement of the socio-cultural and economic status of the state, as well as its level of security and its capacity for defense. This aspect of patriotic education is primarily a matter of interest in the history of education. Another aspect of patriotic education deals with her as a specific moral and social value. A proper interpretation of these values helps to fit patriotism into a broader perspective that transcends toward $s$ universal values. Education in the patriotic spirit can also be regarded as a psychological attitude. In this aspect, the teacher, for example, should pay more attention to the psychological and social conditions of expressing patriotic attitudes, as well as the practical possibilities of their formation. In this approach, the emphasis is not on the analysis of historical and philosophical knowledge about patriotism, but to a much greater degree, on the experiences and active approach to the Homeland and its needs. ${ }^{4}$

The scope of patriotic education at school includes the following goals ${ }^{5}$ :

- formation of ties with the mother country and civic consciousness,

- developing respect for pro-social attitudes and the common good,

\footnotetext{
$1 \quad$ Ustawa z dnia 7 września 1991 r. o systemie oświaty (Dz. U. 2018 poz. 1457).

$2 \quad$ Karta Nauczyciela (Dz. U. z 1982 r. nr 3, poz. 19 z późn.zm.).

3 J. Frątczak, O wychowaniu patriotycznym w szkole, „Nauczyciel i Szkoła” 1 (49) (2011), p. 111-121; Edukacja patriotyczna, https://szkolnictwo.pl/index.php?id=PU8428 (23.10.2018).

4 R. Król, Wychowanie patriotyczne, „Wychowawca” (2004) 4 (136).

5 J. Frątczak, O wychowaniu patriotycznym, p. 111-121; M. Czyż, Edukacja patriotycz$n a$, https://szkolnictwo.pl/index.php?id=PU8428 (20.10.2018.
} 
- shaping respect for your own country,

- developing active participation in the life of the school, local and state community,

- shaping the national identity and participation in nurturing tradition,

- enabling creative participation in cultural and political events,

- developing a sense of responsibility and respect for national symbols,

- shaping appropriate behavior during school and state ceremonies.

The implementation of the indicated goals takes place thanks to the school completing tasks to create situations that trigger an emotional relationship with the mother country, familiarize students with national symbols and important anniversaries, rules and institutions for the country, as well as prepare students for an active and responsible participation in social life. The contents falling within the scope of patriotic education are generally arranged in accordance with the principle of introducing students to what is initially known to them, to go on to what is far and unknown in further stages. As part of teaching about patriotic subjects, the contents presented in schools usually involve familiarizing students with the national emblem and anthem, patriotic songs, literary works (paintings, films, songs), local places of national remembrance, profiles of great Poles from various fields.

Civic education is primarily about group life, including the themes of group relationships and values, social roles, decision making, group conflicts and negotiations, and presentation of content related to local government, citizens' rights and obligations, values and norms of social life, and the definition of categories of common good, social and political culture. ${ }^{6}$ Forms and methods of work with patriotic and civic content include in addition to regular classes in various subjects or educational paths, among others organization of celebrations related to the celebration of national holidays, visiting places of national remembrance, trips to museums and places of historical and cultural importance as well as meetings with interesting people. ${ }^{7}$

Analyzes regarding the basic assumptions of patriotic education indicate that it should be based on the connection of content and tasks from various fields of education, bearing in mind the most harmonious development of various spheres of the child's personality. The shaping of patriotic attitudes

J. Frątczak, O wychowaniu patriotycznym, p. 111-121.

J. Frątczak, O wychowaniu patriotycznym, p. 111-121. 
should be considered from the process of complex educational activity requiring a systematic deepening of the teachers' knowledge, who should learn about contemporary achievements of the theory of needs, the theory of values and the theory of personality. In creating an image of a native country, it is necessary to use the newly acquired elements of knowledge, which are included in the system of information already possessed. Patriotic education is not assigned to a certain age level and should be treated as a life-long long-lasting process, initiated already among very young children. Attachment to the homeland can be awakened already in the group of the youngest children, including starting from their direct surroundings, e.g. place of residence. In this example they can be taught to notice the beauty of their homeland, shaping feelings on this basis, which after many years, will become the leaven of mature patriotism. At certain age levels, especially in the group of young children, patriotic topics are brought closer to visual symbols and signs, including the emblem, state colors, coat of arms and banners. Such materials, due to their colorfulness help to create emotional bonds with the Homeland. Their impact on imagination and feelings is helpful in creating an aesthetic image of Poland. ${ }^{8}$

Patriotism, being a positive attitude towards the Homeland and its problems, should be considered as a foundation of the educational work of all teachers, regardless of the level of education and the subject being pursued. Patriotism should be treated as an attitude expressing not only appreciation of the independence and sovereignty of the Homeland, but also as a day-to-day shaping of general attitudes, observance and respect of the law, conscientious obedience etc. Referring to specific manifestations of patriotic education in the school the examples of the "Core Curriculum" for primary and junior high schools from 2007 on, general education for completion in grades 1-3 may be mentioned. The goal emphasized in the curriculum was to support the feeling of belonging to the school community, local environment, region and country, and such school tasks as making students aware of the great value in the life of every human family, such as family, local environment and homeland. Similarly, in other analogous documents (earlier and later than the cited Core Curriculum), you can find content directly referring to patriotic and civic upbringing. They express

8 G. Kobiela, Patriotyzm polski - wychowanie patriotyczne, „Studia Warmińskie” XLIXLII (2004-2005), p. 391-399. 
themselves in the transfer of knowledge about the local community, for example local authorities, local government structure or participation in the social life of the local environment, school, national culture and its manifestations, profiles of great Poles, the history of the oldest Polish cities, former Polish capitals and the present - Warsaw, as the seat of state authorities and a cultural center. The above issues are usually associated with a wider European context. ${ }^{9}$

Apart from the content of patriotic education, the form of its implementation is also important. With regard to this issue, the need to choose a way of working with students, which will be adequate to the level of their age and their already completed stages of education, will also enable the achievement of the desired didactic and educational goals. Currently, the increasingly popular approach assumes that patriotic topics require the use of learning methods that will not be limited to providing information on the subject, but will also give the opportunity to experience the emotions that will form the foundation for building a patriotic attitude. ${ }^{10}$

Generally, it is assumed that patriotic and civic education should give students the competences that constitute the basis for their implementation through active participation in ever wider social circles ranging from family, school, local community, to the Fatherland and to even wider communities Europe and the world. In this perspective, the analyzed education serves as an introduction not only to the heritage of national, but also European and world culture. A necessary condition for the proper implementation of the patriotic education process should be the students implementation of independent thinking, presenting problems and prompting them to solve these problems. Societal discipline, the economy, independence, responsibility, the constant pursuit of one's own development, feeling the need to know and transform the existing reality are considered to be conducive to such an attitude. ${ }^{11}$

Although the above considerations on patriotic education focused on its educational dimension implemented at school, it must not be forgotten that the foundations of such education are (or at least should be) acquired along with other elements of education in the family home. With regard to the role of the family in the process of patriotic education, it should be noted that according to the teaching of the Church expressed, among

\footnotetext{
9 G. Kobiela, Patriotyzm polski - wychowanie patriotyczne, p. 391-399.

10 G. Kobiela, Patriotyzm polski - wychowanie patriotyczne, p. 391-399.

11 G. Kobiela, Patriotyzm polski - wychowanie patriotyczne, p. 391-399.
} 
others, in the teachings of the Second Vatican Council, education as such is a social endevour, not the accomplishment of an individual. Therefore, in this perspective, three communities, which should play a key role in this process can be identified, Apart from the family, they are the state and the church. The action of the first two concerns the natural order and the last the supernatural order ${ }^{12}$. Due to Polish history, the family traditionally played a special role as a mainstay of Polishness, patriotism and religiosity. ${ }^{13}$ It is true that in the era of great socio-cultural changes, under the influence of the trends of secularism and moral liberalism, as well as the atomization of society and the transformation in the educational sphere, the role of the family in the area of education, including patriotic education seems to be waning, but it is still seen as its the fundamental foundation. Patriotic education, in this approach, is part of a wider process, which also involves the transmission of certain moral-religious and ethical-moral values. ${ }^{14}$

When analyzing the issue of patriotic education in the family, it should be noted that many contemporary pedagogical trends give it a very limited scope of attention, or ignore it completely. For example, in "praxeological" pedagogy, for which "performance" becomes the supreme criterion, the subject of such education almost does not appear. Similarly in the socalled "Evolutionary programs of education", the theme of patriotism is not present because the fundamental inspiration in this approach is the "post-Christian era". Very little space to the subject of patriotic education is also devoted in so called "Situational ethics and pedagogy", which focuses primarily on the creativity of "self" and on the total "freedom of behavior" and vision of reality as "game". Moreover trends focusing on the sociological

12 S. Cader, Rodzina środowiskiem wychowawczym w świetle nauczania Jana Pawła II, Kraków 2004, p. 40.

13 E. Osewska, Polska rodzina jako środowisko wychowania religijnego, in: Rodzina $w$ trosce o życie - Kościół $w$ trosce o rodzinę, ed. R. Buchta, Katowice 2010, p. 60-69; J. Stala, Christliche Wahrheiten als Fundament einer inhaltsreichen Religionserziehung in der Familie, „The Person and the Challenges“ 5 (2015) nr 2, pp. 137-148; J. Stala, Geistig behinderte Kinder religiös erziehen - Herausforderungen an Pädagogik und Katechese, "The Person and the Challenges" 4 (2014) nr 2, pp. 221-234; J. Stala, W kierunku integralnej edukacji religijnej w rodzinie. Próba refleksji nad nauczaniem Jana Pawła II w kontekście polskich uwarunkowań, Tarnów 2010; Religious Education / Catechesis in the Family. A European Perspective, eds. E. Osewska, J. Stala, Warszawa 2010.

14 E. Osewska, Wspólnota rodzinna w stużbie wychowania, „Family Forum” (2014), No. 4, p. 125-139; I. Celary, Wychowanie patriotyczne w rodzinie chrześcijańskiej, „Perspectiva. Legnickie Studia Teologiczno-Historyczne” IX (2010)1 (16), p. 10. 
or psychological approach to education, put their emphasis, respectively, on the processes of socialization or personality development. The subject of patriotic education in the family is also ignored (which should not be surprising) in educational ideologies related to totalitarian and liberal ideologies, where education mainly relates to the process implemented institutionally and as part of socialization. ${ }^{15}$

In a traditional approach referring to Christian thought, the family, through patriotic education, includes its pupils in a specific socio-cultural trend. Patriotic education is treated here as an integral part of the native culture. ${ }^{16}$ The family is a natural environment, where individuals acquire the achievements of national culture for the first time. It is within the family that man acquaints himself with all the values, and treats those values as a foundation of his later attitude, whereby values are treated as something found, reproduced, created and realized at the same time. Thanks to this, the family shapes human relations to such communities as the nation and the state, becoming the primary environment of building a national consciousness and patriotic attitudes. ${ }^{17}$

In the Polish educational system elements of patriotic upbringing presented during school catechesis classes are a kind of bridge between the patriotic upbringing in the family home and patriotic-civic education implemented at school. ${ }^{18}$ The basic directions of patriotic education in the school teaching of religion were set in the core curriculum of the catechesis of the Catholic Church ${ }^{19}$ and in the Curriculum of Religions developed for junior high school and profiled secondary schools. ${ }^{20}$ The content of those documents regarding patriotic and civic education indicates, to a great extent, a correlation between the teaching of religion and other subjects or educational paths. This link remains valid despite the fact that Polish junior

15 I. Celary, Wychowanie patriotyczne w rodzinie chrześcijańskiej, p. 11.

16 K. Popielisk, Wartości i ich znaczenie w życiu ludzi, in: Wartości - człowiek - sens, ed. K. Popielisk, Lublin 1994, p. 62.

17 L. Dyczewski, Rodzina - społeczeństwo - państwo, Lublin 1994, p. 47-48.

18 E. Osewska, Praktyka katechezy rodzinnej na świecie, „Seminare” (1999) 15, p. 219-231.

19 Konferencja Episkopatu Polski, Podstawa programowa katechezy Kościoła katolickiego w Polsce, Kraków 2001, p. 12, 45-47, 64-68, 84-93.

20 Program nauczania religii dla gimnazjum „Wierzyć Chrystusowi”, AZ-3-01/1, in: Komisja Wychowania Katolickiego Konferencji Episkopatu Polski, Program nauczania religii, Kraków 2001, p. 94, 98, 101. 
high school has been replaced byeighth-grade primary school. The above mentioned documents refer to the indications of the Catechetical Directory of the Catholic Church in Poland. ${ }^{21}$ This document states, among others, that the teaching of religion at school performs an auxiliary function towards the family, recognizing as one of its main goals the restoration of the education system's proper axiological plane. Furthermore, the teaching of religion at school is to focus not only on religious values, but also on their integration with culture, including their native culture. ${ }^{22}$

Issues in the field of patriotic education in the catechetical program have been linked to topics in the area of history, knowledge about society, regional education, and Polish culture as compared to the Mediterranean tradition and participation in culture. An example of the integration of patriotic content with other areas of knowledge as part of the teaching of catechesis was the program-based curriculum of religion teaching in the junior high school. Within this framework, such content focused on issues identified within the framework of history and three thematic modules of knowledge about society (which include education for family life, civic education and upbringing to active participation in economic life). ${ }^{23}$

The indicated areas of correlation propose the transfer of knowledge about national tradition and Catholic social science, and above all, the familiarization with civil rights and duties. At the basis of such an approach is the assumption that a good knowledge of tradition, history, culture, values related to the homeland and present conditions is the foundation of patriotic education. Emphasis on stories does not exclude the critical judgment of your own historical past. The aspects of civic education focus on shaping an attitude of respect towards the nation and state institutions, with a special value attributed to the formation of responsibility for the future of the fatherland in young people. ${ }^{24}$

Review of issues in the field of patriotic education presented in the teaching of religion (now and the past), point to some preferences of issues

\footnotetext{
${ }^{21}$ Konferencja Episkopatu Polski, Dyrektorium katechetyczne Kościoła katolickiego w Polsce, Kraków 2001, 83.

22 Konferencja Episkopatu Polski, Dyrektorium katechetyczne Kościoła katolickiego w Polsce, Kraków 2001, 85.

23 A. Zellma, Wychowanie patriotyczne współczesnej młodzieży polskiej w szkolnym nauczaniu religii, „Studia Warmińskie” (2003) 40, p. 183-197.

24 Konferencja Episkopatu Polski, Katecheza wyznania i rozumienia wiary - gimnazjum, in: Podstawa programowa katechezy Kościoła katolickiego w Polsce, p. 56-63.
} 
that treat Polish national consciousness, the ethos of the Polish nation and the true and active love of the fatherland, manifesting itself in the history of the nation, in an attitude of respect towards another man, in acquiring and displaying social behaviors conducive to the protection of national heritage and care for the development of national culture and the natural environment. In the presented approach, it is assumed that during school catechesis, the pursuit of shaping the personal identity of young people should take place in the context of the national values, supports students in recognizing the importance of the values of their own fatherland in personal life, and in forming an attitude of national solidarity and openness to other communities. ${ }^{25}$

In the general perspective, the elements of patriotic education in teaching religion are presented through the prism of Christian values, giving them a more universal character. It should also be emphasized that religious inspiration in patriotic education determines the directions of educational interactions, emphasizing the moral dimension of such education.

\section{Regional and local education as an element of patriotic education}

When analyzing the issue of patriotic education, it should be emphasized that currently such programs of education are often closely related to regional and local education. Regional education refers primarily to the history of the territory, which, in the past, showed a distinct political, administrative, cultural and economic autonomy. Education of a local character refers to the history of the nearest neighborhood, district, street, city, school, workplace, town or village. In both cases, we deal with the history of the so-called small homeland, which has been recorded in regional and local publications, traditions, historical places, monuments of nature and culture constituting national heritage, which strengthen bonds with the place of residence

25 Konferencja Episkopatu Polski, Katecheza świadectwa wiary - szkoły ponadgimnazjalne, in: Podstawa programowa katechezy Kościoła katolickiego w Polsce, p. 81-93. About teaching religion and its broader educational context in England and Wales: Cf. E. Osewska, Edukacja religijna $w$ szkole katolickiej $w$ Anglii $i$ Walii $w$ świetle Living and Sharing our Faith. A National Project of Catechesis and Religious Education, Tarnów 2008, p. 69-117. 
and strengthen attachment to family places. ${ }^{26}$ As in the case of patriotic education in general, also in relation to regional and local education, there is a need to teach them in a way that integrates various subjects. Along with history, education of the analyzed character should include elements of: the Polish language, knowledge about society, religion, geography and even technical classes or entrepreneurship. The implementation of regional education can take place in two basic ways, as: regionalization of teaching or regional teaching. The first of these, regionalization of teaching, is manifested in emphasizing the existing curricula, the content related to the region through the exchange of some existing content into the regional, or by adding content specific to the region. Regional teaching, on the other hand, is understood as a specific selection of regional values and contents of a general character made by the interested persons themselves in order to pass them on to the next generation as a cultural value. The general understanding of regional education assumes an approach to it as an integrated process shaping and stabilizing attitudes towards the heritage of the past and contemporary problems of its own region. Its aim is to help in the conscious shaping of one's identity and to maintain the continuity of culture, as well as to place those regional aspects within the national and more broadly European context. ${ }^{27}$

In the context of patriotic education, regional education is treated as one of the sources of national identity. In this approach, knowledge about your own region is directly related to the ability to solve problems concerning the region, which in turn allows you to understand problems of a more complex nature. Regional (and local) education is referred to in some terms as environmental education. ${ }^{28} \mathrm{~A}$ fuller understanding of one's own or regional and local culture, including historical heritage, allows for the extraction of various values inherent in its own region in connection with national values, but also in a more universal context. In this approach the

26 T. Stachurska-Maj, Wychowanie patriotyczne $w$ korelacji międzyprzedmiotowej, „Trendy”(2016) 2-3, p. 15-19.

27 Pojęcie edukacji regionalnej, jej cele i zadania. https://www.szkolnictwo.pl/index. php?id=PU5494 (24.10.2018).

28 W. Theiss, Szkoła i edukacja środowiskowa, „Wychowanie na co Dzień” (1999) 1-2, p. 3-5. 
citizens of both their country and their small homeland are formed, being conscious of their abilities and duties and remaining open to other cultures. ${ }^{29}$

The main and auxiliary purposes of regional education may be formulated differently depending on the position held. Some of them perceive this form of education as combining knowledge about their own region with their knowledge about their own country and nation. It should also provide knowledge about the international situation in the context of its links with various areas of its own regional environment. An important element of regional education should also be geographical knowledge about the location of the region, its climate, terrain, nature, as well as knowledge about the demographics of the local community or the economy of the region. Of course, a very important part of this education should be knowledge of the regional and local traditions. Regional education should not be limited only to the local perspective, but should also take into account the universal context, for example by looking for regional values that can be considered in the context of national, state and human values.

In regional education, the knowledge of the region should be transmitted through the prism of material, spiritual, intellectual, moral and religious values which will enable the formation of the so-called ethos( lifestyle) of the community. Moreover, it is important from the perspective of regional education, to familiarize students with the manifestations of the local environment. The cultural awareness of one's own region should not lead to the formation of a narrowly defined identity but rather the formation of a "pluralistic identity" that embraces the feeling of self-differentness while maintaining an open, tolerant attitude, focused on understanding different human cultures. ${ }^{30}$

Patriotism, in this perspective, should be taught through the awakening of love for small homelands, with the help of cultural narratives that are transmitted to students from an early age in their immediate family and social surrounding. Passing knowledge about your region through highlighting environmental diversity, local ethnography for example, traditions, rituals and monuments as an intrinsic part of a national heritage gives one the opportunity to develop from a local community member to a fully-fledged

29 S. Bednarek ed., Edukacja regionalna - dziedzictwo kulturowe $w$ zreformowanej szkole, Wrocław 1999, p. 134-139.

30 S. Bednarek ed., Edukacja regionalna - dziedzictwo kulturowe w zreformowanej szkole, p. 134-139. 
citizen. ${ }^{31}$ It is assumed that the formation of a sense of regional identity in the education process should be carried out with the use and observance of several important principles ${ }^{32}$ :

- teaching should take into account examples related to the local community, the small homeland and region in the context of their links with national history and culture, etc.;

- deepening knowledge about the specificity of your own region favors the strengthening of the sense of national identity, because the nation is a "imaginative community" for children, especially the younger ones, which exists more clearly and is marked more strongly by identification with "a small homeland";

- the formation of the local identity is based on the separation of the relatively autonomous and characteristic values for your own region;

- distinguishing adapted (borrowed) values from other regions or other cultural circles should also help to develop a sense of interdependence and transmission of cultural values among students, thus increasing the sense of respect and openness to values other than family, regional or national values;

- the presentation of historical and contemporary Polish culture in co-creation with other cultures and the impact of different cultures on native culture, which forms the basis for shaping the attitude of tolerance towards diversity and cultural differences.

This approach to local and regional education allows it to be treated as an important source and component not only of patriotic education, but also as an element of teaching of a more universal nature, going beyond the circle of national culture.

31 B. Dudel, Tematyka patriotyczna $w$ kształceniu zintegrowanym i propozycje jej realizacji ( $w$ wybranych czasopismach metodycznych), in: Patriotyzm a wychowanie, eds. E. J. Kryńska, J. Dąbrowska, A. Szarkowska, U. Wróblewska, Białystok 2009, p. 617-623.

32 B. Dudel, Tematyka patriotyczna $w$ kształceniu zintegrowanym i propozycje jej realizacji, Białystok 2009, p. 617-623. 


\section{Bibliography}

Bednarek S. ed., Edukacja regionalna - dziedzictwo kulturowe w zreformowanej szkole, Wrocław 1999.

Cader S., Rodzina środowiskiem wychowawczym w świetle nauczania Jana Pawła II, Kraków 2004.

Celary I., Wychowanie patriotyczne $w$ rodzinie chrześcijańskiej, „Perspectiva, Legnickie Studia Teologiczno-Historyczne” IX (2010)1(16).

Czyż M., Edukacjapatriotyczna, https://szkolnictwo.pl/index.php?id=PU8428 (20.10.2018).

Dudel B., Tematyka patriotyczna w ksztatceniu zintegrowanym i propozycje jej realizacji ( $w$ wybranych czasopismach metodycznych), in: Patriotyzm a wychowanie, eds. E. J. Kryńska, J. Dąbrowska, A. Szarkowska, U. Wróblewska, Białystok 2009, p. 617-623.

Dyczewski L., Rodzina - społeczeństwo - państwo, Lublin 1994.

Edukacja patriotyczna, https://szkolnictwo.pl/index.php?id=PU8428 (23.10.2018).

Frątczak J., O wychowaniu patriotycznym w szkole, "Nauczyciel i Szkoła" (2011) 1, p. 111-121.

Kobiela G., Patriotyzm polski - wychowanie patriotyczne, "Studia Warmińskie" XLI-XLII (2004-2005), p. 391-399.

Komisja Wychowania Katolickiego Konferencji Episkopatu Polski, Program nauczania religii, Kraków 2001.

Konferencja Episkopatu Polski, Dyrektorium katechetyczne Kościoła katolickiego w Polsce, Kraków 2001.

Konferencja Episkopatu Polski, Podstawa programowa katechezy Kościoła katolickiego w Polsce, Kraków 2001.

Osewska E., Edukacja religijna w szkole katolickiej w Anglii i Walii wświetle Living and Sharing our Faith. A National Project of Catechesis and Religious Education, Tarnów 2008.

Osewska E., Polska rodzina jako środowisko wychowania religijnego, in: Rodzina $w$ trosce o życie - Kościół w trosce o rodzinę, ed. R. Buchta, Katowice 2010, p. 60-69.

Osewska E., Praktyka katechezy rodzinnej na świecie, "Seminare" (1999) 15, p. 219-231. 
Osewska E., Wspólnota rodzinna w służbie wychowania, „Family Forum” (2014) 4, p. 125-139.

Pojęcie edukacji regionalnej, jej cele i zadania, https://www.szkolnictwo.pl/ index.php?id=PU5494 (24.10.2018).

Popielisk K., Wartości i ich znaczenie w życiu ludzi, in: Wartości - człowiek sens, ed. K. Popielisk, Lublin 1994.

Religious Education / Catechesis in the Family. A European Perspective, eds. E. Osewska, J. Stala, Warszawa 2010.

Stachurska-Maj T., Wychowanie patriotyczne w korelacji międzyprzedmiotowej, „Trendy” (2016) 2-3.

Stala J., Christliche Wahrheiten als Fundament einer inhaltsreichen Religionserziehung in der Familie, "The Person and the Challenges" 5 (2015) nr 2, pp. 137-148.

Stala J., Geistig behinderte Kinder religiös erziehen - Herausforderungen an Pädagogik und Katechese, "The Person and the Challenges" 4 (2014) nr 2, pp. 221-234.

Stala J., W kierunku integralnej edukacji religijnej w rodzinie. Próba refleksji nad nauczaniem Jana Pawła II w kontekście polskich uwarunkowań, Tarnów 2010.

Theiss W., Szkoła i edukacja środowiskowa, "Wychowanie na co Dzień" (1999) 1-2.

Zellma A., Wychowanie patriotyczne współczesnej młodzieży polskiej w szkolnym nauczaniu religii, "Studia Warmińskie" (2003) 40.

\section{Legal acts}

Ustawa z dnia 7 września 1991 r. o systemie oświaty (Dz. U. 2018, poz. 1457). Karta Nauczyciela (Dz. U. z 1982 r. nr 3, poz. 19 z późn. zm.). 